\title{
Efektivitas Terapi Membaca Al-Fatihah Reflektif-Intuitif dalam Menurunkan Depresi Penyintas Autoimun
}

\author{
Infanti Wisnu Wardani ${ }^{1}$, Fuad Nashori ${ }^{2 *}$ \\ Universitas Islam Indonesia Yogyakarta \\ ${ }^{1}$ infanti.wisnu@gmail.com, ${ }^{2}$ fuadnashori@uii.ac.id \\ *Correspondence
}

\section{Article Information: \\ Received 30 January 2021 \\ Revised 03 September 2021 \\ Accepted 14 September 2021}

Keywords:

depression; reflectiveintuitive therapy of alfatihah; autoimmune

\section{Kata Kunci:}

depresi; terapi al-fatihah reflektif-intuitif; autoimun
This study aims to observe the effectiveness of therapy of reflective-intuitive reading of Al-Fatihah in reducing the depression of autoimmune survivors. It used the quasiexperiment with the pre-test-posttest control group design - not non-randomized pretest-posttest control group design. The subjects involved in this study were the female Moslems becoming the survivors of one of the autoimmune diseases. Here, the level of depression of the subject was measured using the Depression Anxiety Stress Scale (DASS) sub-test of depression developed by Lovibond and Lovibond, adapted into the Indonesian language. The implementation of the therapy refers to the module of reflective-intuitive reading of Al-Fatihah developed by the researcher and team by referring to the module owned by Maulana, Subandi and Astuti. Data analysis used the Mann Whitney U-Test to determine the difference in the depression level in the experimental group before and after the intervention compared to the control group. The study results showed that therapy of reflective-intuitive reading of Al-Fatihah effectively reduced the level of depression of autoimmune survivors after passing the changing process taking a particular time.

Penelitian ini bertujuan untuk mengetahui efektivitas terapi membaca Al-Fatihah reflektif-intuitif dalam menurunkan depresi pada penyintas autoimun. Metode yang digunakan dalam penelitian ini adalah metode kuasi eksperimen dengan desain kelompok control prates-pascates bukan random (non randomized pretest-posttest control group design). Subjek yang dilibatkan dalam penelitian ini adalah perempuan yang beragama Islam dan menjadi penyintas salah satu penyakit autoimun. Tingkat depresi dalam penelitian ini diukur menggunakan skala Depression Anxiety Stress Scale (DASS) subtes depresi yang dikembangkan oleh (Lovibond \& Lovibond, 1995)yang sudah diadaptasi ke dalam bahasa Indonesia. Pelaksanaan terapi mengacu pada modul membaca Al-Fatihah reflektif-intuitif yang dikembangkan peneliti bersama tim dengan merujuk pada modul yang disusun Maulana, Subandi dan Astuti. Analisis data menggunakan uji Mann Whitney U-Test untuk mengetahui perbedaan tingkat depresi pada kelompok eksperimen di saat

Copyright holder ( $) 2021$ Infanti Wisnu Wardani, Fuad Nashori This article is licensed under CC-BY-SA | 196 
sebelum dan sesudah intervensi dibandingkan dengan kelompok kontrol. Hasil penelitian menunjukkan bahwa terapi membaca Al-Fatihah reflektif-intuitif efektif dalam menurunkan tingkat depresi pada penyintas autoimun setelah melewati proses perubahan yang memakan waktu tertentu.

\section{PENDAHULUAN}

Penyakit autoimun adalah respon imun didalam tubuh terhadap antigen yang terjadi karena kegagalan mekanisme normal untuk mempertahankan diri sendiri. Sistem imun tersebut seharusnya hanya menyerang zat asing yang membahayakan tubuh sehingga tidak memunculkan permasalahan fisiologis (Robbins, 2010). Permasalahan fisiologis tersebut dapat dikenali dengan tanda klasik berupa inflamasi pada bagian tubuh yang diserang oleh autoimun (Singh dkk., 2016).

Penyakit autoimun dapat dikelompokkan menjadi dua kategori, yaitu gangguan organ tunggal dan gangguan sistemik. Gangguan organ tunggal berarti sistem imun dalam tubuh menyerang satu organ tertentu, sedangkan gangguan sistemik berarti sistem imun tubug menyerang beberapa organ (Robbins, 2010). Beberapa penyakit yang termasuk dalam autoimun antara lain Lupus Eritemetosus Sistemik (SLE), multipel sklerosis, Juvenile Idiopatik Artritis (JIA), diabetes mellitus tipe 1, sindrom grave, dan scleroderma (US Department of Health and Human Services, 2005).

Sejak berakhirnya perang dunia kedua autoimun terus meningkat secara global baik secara insidensi maupun prevalensinya (AARDA, 2016). Hasil penelitian yang dilakukan oleh (Fairweather dkk., 2008) menunjukkan bahwa sekitar 8\% populasi di dunia menderita penyakit autoimun dan $78 \%$ di antaranya adalah perempuan. Autoimun merupakan penyakit yang mematikan di Amerika Serikat dan menduduki urutan ketiga. Penderita autoimun terbanyak adalah perempuan dan anak-anak yaitu sekitar $80 \%$ dari 50 juta jiwa. Sedangkan prevalensi di Indonesia sendiri memiliki mendekati Amerika, yaitu sekitar 40 juta jiwa (Cardoba, 2017). Berdasarkan hasil pengamatan diketahui bahwa terjadi peningkatan yang signifikan terhadap penyakit autoimun. Meskipun demikian, etiologi dan patogenesis dari autoimun ini belum bisa diketahui (Vojdani, 2014). Berdasarkan hasil penelitian yang dilakukan oleh (Diantini dkk., 2016) diketahui bahwa pada periode Januari 2015 - Juni 2016 terdapat 50 penyintas dari 22.881 (sekitar $0,22 \%$ ) anak di RSUP Sanglah Denpasar menderita penyakit autoimun. Selain itu didapatkan data bahwa SLE merupakan kasus autoimun terbanyak yang terjadi pada 25 orang dari 50 penyintas, berada pada usia di atas 10 tahun dan banyak terjadi pada perempuan.

Saat ini semakin banyak literatur yang menunjukkan hubungan antara depresi dan kesehatan fisik, terutama yang berkaitan dengan dengan gangguan disfungsi dari sistem imun (Penninx dkk., 2013). Sebagai contoh, ditemukan bahwa depresi berkaitan dengan peningkatan risiko timbulnya dan perkembangan penyakit kronis, seperti penyakit kardiovaskular, neuroplastik, dan neurodegeneratif (Penninx dkk., 2013). Hingga saat ini beberapa penelitian telah meneliti tentang hubungan antara depresi dan penyakit 
autoimun. Berdasarkan penelitian (Pryce \& Fontana, 2016) diketahui bahwa hingga 50\% pasien dengan penyakit autoimun menunjukkan penurunan kualitas hidup berupa kesehatan dan menunjukkan gejala depresi. Selain itu, berberapa penelitian yang berdasarkan komunitas menunjukkan hubungan antara depresi dan beberapa jenis autoimun (Matcham dkk., 2013) Hubungan antara penyakit autoimun dan depresi pada individu tidak hanya terjadi satu arah namun juga ada kemungkinan terjadi dua arah (Kiecolt-Glasera \& Glaser, 2002). Beberapa peneilitian tersebut sejalan dengan hasil wawancara yang dilakukan kepada penyintas autoimun jSystemic Lupus Erythematosus (SLE) dan Psoriasis.

Wawancara yang dilakukan kepada penyintas autoimun bernama V (10/01/2019) menunjukkan bahwa dirinya merasa panik ketika dokter menyampaikan hasil tes kesehatannya. Yang ada dalam pikiran $\mathrm{V}$ adalah pasti penyakit yang dokter katakan sangat berat dan serius. V didiagnosis mengalami SLE. V merupakan seorang wanita berusia 30 tahun dan memiliki satu orang anak. Saat ini V hanya tinggal bersama anaknya, sedangkan suaminya bekerja di kota yang berbeda. Setelah V mendapatkan penjelasan dari dokter mengenai penyakitnya, $\mathrm{V}$ merasa tidak percaya dengan apa yang disampaikan dokter. Akhirnya V mencari-cari tentang penyakit autoimun dari internet. Semakin V tahu soal apa yang sedang dideritanya, V merasa dunianya semakin sunyi dan merasa sendirian. Keberadaan suaminya yang jauh di luar kota menjadi stressor tersendiri. Proses pemeriksaan yang dilakukan cukup panjang dan V diharuskan untuk terus mengkonsumsi obat-obatan dan menjaga makanan serta pola hidup. Selain memikirkan tentang penyakitnya, V juga memikirkan anaknya yang masih kecil. Kondisi tersebut semakin membuat $\mathrm{V}$ tertekan. Kondisi fisik yang semakin melemah membuat V membatasi aktifitasnya sehingga $\mathrm{V}$ memutuskan untuk menarik diri dari lingkungan sosialnya.

Wawancara juga dilakukan pada penyintas autoimun jenis psoriasis. Hasil wawancara kepada penyintas autoimun I (13/01/2019) mengungkapkan bahwa I merasa bersalah dan tidak berguna dalam hidupnya. Sebelumnya I (wanita, 27 tahun) merupakan seorang karyawan perusahaan swasta, namun setelah penyakitnya semakin parah, I memutuskan untuk berhenti bekerja. Sebenarnya I merasa kecewa karena harus berhenti bekerja namun kondisi fisik yang kelelahan seringkali membuat penyakitnya semakin parah. Kondisi kulit yang bersisik dan menyebabkan luka membuat I merasa malu jika bertemu orang lain. Bagi gadis seusia I, penampilan fisik merupakan hal yang sangat diperhatikan, tidak jarang I merasa sangat frustrasi akan hal itu. I juga sempat berfikir untuk mengakhiri hidup karena merasa tidak berharga, tidak berguna lagi dan tidak ada yang mau berteman dengan I.

Berdasarkan hasil wawancara tersebut, diketahui bahwa penyintas sering kali merasa cemas terhadap penyakit yang dideritanya dan memiliki pemikiran-pemikiran bahwa mereka akan segera meninggal. Mereka juga menarik diri dari lingkungan sosial karena adanya perubahan fisiologis yang terjadi. Selain itu, para penyintas juga harus mengkonsumsi obat setiap hari, mengatur pola makan dan pola hidup. Hal tersebut 
memberikan tekanan tersendiri bagi para penyintas autoimun, tidak jarang mereka berpikir ingin mengakhiri hidup agar tidak merasa susah. (Maria \& Ediati, 2018) menyatakan bahwa peran sosial Odapus (Orang dengan lupus) banyak dipengaruhi oleh kualitas hidup baik secara psikis dan fisik.

Mattje dan Turato (Laeli, 2016) menemukan bahwa odapus mengalami kesulitan untuk menerima penyakit yang dialami, namun mereka menyadari untuk berjuang melawan penyakitnya dan berjuang untuk sembuh. Penelitian lain yang dilakukan oleh (Wahyuningsih \& Surjaningrum, 2013) mengemukakan bahwa penyintas lupus wanita pada rentang usia dewasa awal dan sudah menikah mengalami permasalahan yang sama. Permasalahan yang mereka alami adalah permasalahan psikologi dan permasalahan sosial. Permasalahan sosial juga dialami oleh individu dengan psoriasis. Dalam penelitian (Sinaga, 2013) disebutkan bahwa psoriasis merupakan penyakit akut dan dapat timbul kembali yang yang menyerang bagian kulit dan dapat mempengaruhi citra tubuh dan harga diri penyintasnya.

Sarafino dan Smith (2011) mengatakan bahwa untuk pertama kali individu akan kaget ketika menerima diagnosis suatu penyakit kronis. Perasaan tersebut dapat berlangsung cepat ataupun berlanjut dalam hitungan minggu. Setelah perasaan kaget, penyintas akan mengalami encounter. Kondisi ini ditandai dengan adanya kesalahan dalam proses berfikir, adanya perasaan kehilangan, tidak berdaya, sedih, dan putus asa. Selama fase ini, penyintas sering merasa kesusahan dalam menghadapi kenyataan yang terjadi dan merasa tidak memiliki rencana yang efektif mencari solusi. Reaksi selanjutnya adalah retreat, yaitu penyintas cenderung melakukan penyangkalan jika memiliki permasalahan terkait kesehatannya. Stressor yang tidak segera teratasi memiliki potensi menimbulkan gangguan psikologis seperti depresi.

Depresi yang dialami dapat merusak sistem otak yaitu pada bagian sistem neuroendokrin yang mengakibatkan perubahan sekresi pada ACTH (Parker dkk., 2003). Depresi yang dibiarkan terus menerus akan merusak system kekebalan tubuh atau imunitas (Dirgayunita, 2016). Imun tersebut bertugas untuk melawan benda asing yang ada didalam tubuh atau yang biasa disebut dengan respon imun (Abbas, 2000; Herowitz, 1993). Beberapa penelitian terbaru menunjukkan bahwa adanya gangguan psikologis yang mempengaruhi turunnya kemampuan imunitas dan dapat ditinjau dari sisi religiusitas (Mustamir, 2007; (Ong dkk., 2006). Beberapa penelitian mengungkapkan bahwa religiusitas memberikan dampak positif terhadap penyembuhan seseorang ((Kane, 2006). Hal ini dipengaruhi oleh tingkat pengetahuan, pelaksanaan, keyakinan dan juga penghayatan individu terhadap ajaran agamanya (Ancok \& Suroso, 2018).

Berbagai riset dengan pendekatan religiusitas telah dilakukan dalam usaha menurunkan tingkat depresi dan terbukti dapat menurunkan tingkat depresi pada individu. Nashori, Diana, dan Hidayat mengungkapkan bahwa intervensi psikologi Islam yang merujuk pada al-Quran dan hadis Nabi efektif dalam menurunkan berbagai gangguan psikologis, seperti depresi, stres, dan kecemasan, prokrastinasi akademik, gangguan 
obsesif-kompulsif, dan perilaku seks pranikah. Penelitian yang dilakukan oleh (Elliya dkk., 2018) menunjukkan bahwa religiusitas dapat mempengaruhi tingkat depresi pada lansia beragama Islam di UPTD pelayanan Sosial Tresna Werdha Natar Lampung Selatan. Selain itu, sebuah penelitian (Khan dkk., 2010) menunjukkan bahwa visualisasi dan sistem multimedia dalam membaca Al-Quran dapat memberikan ketenangan, menghilangkan rasa bosan, lelah, stres dan depresi. Al-Quran yang dibaca setiap hari secara rutin akan memberikan efek permanen dan bertahan lama. Penelitian yang dilakukan oleh (Julianto \& Etsem, 2011) menyebutkan bahwa mendengarkan pembacaan Al-Quran akan menimbulkan rasa tenang dan akan mengaktifkan gelombang alpha pada jaringan otak. Meskipun demikian, di dalam kitab suci Al-Qur'an terdapat surat pendek yang seringkali dibaca setiap hari dan hampir setiap muslim mengetahui artinya. Surat tersebut adalah surat Al-Fatihah.

Hamka (1982) menyebutkan bahwa banyak sekali keistimewaan yang dimiliki surat Al-Fatihah. Pertama, Al-Fatihah merupakan surat pembuka dalam Al-Quran. Kedua, surat Al-Fatihah menjadi syarat sah dalam sholat lima waktu. Ketiga, Al-Fatihah merupakan surat yang diturunkan kepada Nabi Muhammad SAW secara lengkap. Keempat, surat Al-Fatihah merupakan surat yang selalu diulang dalam setiap rakaat sholat. Kelima, Imam Bukhari menyebut bahwa surat Al-Fatihah merupakan ummul kitab. Keenam, surat Al-Fatihah merupakan al-waqiyah (pemelihara dari kesesatan) karena surat Al-Fatihah melengkapi surat yang lain. Keistimewaan yang keetujuh adalah mulai dari ayat pertama hingga ayat terakhir mengejarkan tentang pokok ajaran islam sejati yaitu tauhid (Ansyah \& Hadi, 2017). Al-Jauziah (2011) juga menyebutkan bahwa AlFatihah memiliki nama lain, yaitu asy-syafiyah (penyembuhan) yang artinya surat AlFatihah memiliki potensi terapeutik yang dapat digunakan untuk mengatasi gangguang psikologis.

Membaca Al-Fatihah harus dilakukan dengan benar dan memahami makna yang terkandung didalamnya (Iim, 2003). Menurut (Matlin, 2009), suatu informasi akan diingat apabila dilakukan secara mendalam. Hal ini dapat diartikan bahwa Surat AlFatihah akan lebih diingat apabila pembacanya mengetahui kandungan makna didalamnya (Julianto \& Subandi, 2015). Sejalan dengan hal tersebut Julianto dan Subandi mengembangkan cara membaca Al-Fatihah secara reflektif dan intuitif yang digunakan sebagai terapi.

Membaca surat Al-Fatihah secara reflektif-intuitif merupakan cara membaca ayat Al Quran yang diinternalisasikan secara berulang keadalam diri individu. (Julianto \& Subandi, 2015) mengatakan bahwa hal tersebut dapat memberikan pemahaman dan motivasi terkait pandangan akan pegangan hidup yaitu Allah. Terapi Al-Fatihah reflektifintuitif dilakukan dengan membaca surat Al-Fatihah yang diikuti proses berpikir, memahami dan merasakan makna dari setiap ayat pada surat Al-Fatihah dan dilakukan dengan pendekatan regiusitas (Yudhani dkk., 2017). terapi ini dilakukan dengan cara melakukan tadabbur terhadap ayat-ayat surat Al-Fatihah (Ningsih, 2020). Tadabbur 
memiliki makna usaha yang dilakukan untuk mengetahui dan memahami makna yang terkandung dalam ayat Al-Quran (Asyafah, 2016). (Yudhani dkk., 2017) menerangkan bahwa refleksi sama halnya dengan tadabbur yang mengandung makna berpikir dengan serius. Terapi ini nantinya juga dilakukan melalui proses intuitif. Menurut Maulana, Subandi dan Astuti (2016) intuisi merupakan sebuah kemampuan yang dimiliki untuk mengetahui suatu hal yang bersumber pada batin. (Ningsih, 2020) menyimpulkan bahwa intuitif adalah perasaan terhadap kemampuan diri yang sebelumnya belum pernah dipelajari.

Pada proses terapi Al-Fatihah reflektif-intuitif, peserta diminta untuk mendengarkan dan membaca sehingga dapat berpengaruh pada bagian otak tengah yaitu superior colliculi dan inferior colliculi yang berpengaruh langsung pada tubuh dibanding hanya dengan dibaca (Mahmuda dkk., 2018). Penelitian yang dilakukan oleh Maulana, Subandi dan Astuti (2016) mengatakan bahwa terapi Al-Fatihah reflektif-intuitif memiliki manfaat untuk meningkatkan rasa ketergantungan individu kepada Allah.

Beberapa peneliti sudah melakukan penelitian tentang efekivitas terapi membaca Al-Fatihah Reflektif-intuitif dalam mengatasi gangguan psikologis. Riset (Julianto \& Subandi, 2015) mengkaji pengaruh membaca Al-Fatihah reflektif-intuitif terhadap penurunan depresi dan peningkatan Imunitas. Hasil dari penelitian tersebut menunjukkan bahwa membaca Al-Fatihah reflektif-intuitif dapat mengubah pandangan subjek terhadap permasalahan dalam hidupnya. Penelitian lainnya dilakukan oleh (Julianto dkk., 2017) juga membuktikan bahwa membaca Al-Fatihah reflektif-intuitif dapat menurunkan kecemasan berbicara di depan umum pada mahasiswa. Selain terbukti efektif dalam menurunkan tingkat kecemasan dan depresi, terapi refleksi Al-Fatihah juga mampu memberikan penguatan terhadap pikiran manusia (Yanda dkk., t.t.).

Berdasarkan penelitian-penelitian tersebut telah terbukti bahwa bahwa terapi AlFatihah reflektif-intuitif dapat menurunkan tingkat depresi seseorang. Menurut Riyono (2012), hal ini terjadi karena individu memiliki kecenderungan memandang peristiwa yang terjadi dalam hidup melalui sudut pandang selain Allah. Pada saat mengalami depresi, seseorang akan cenderung kehilangan pegangan (anchor) yang selama ini diandalkan. Selama ini banyak individu yang mengandalkan anchor lain seperti materi dan orang lain, namun dalam beberapa kondisi individu tidak dapat terus menerus mengandalkan hal tersebut. Ketidakstabilan psikologis dapat disebabkan oleh kesalahan seseorang dalam memposisikan pegangan (anchor) yang mereka miliki. Terapi refleksi Al-Fatihah dapat membantu individu menemukan pegangan (anchor) mereka melalui kegiatan refleksi prinsip-prinsip kebaikan Allah, kasih sayang dan cinta Allah ke dalam proses kehidupannya.

Intervensi kepada penyintas autoimun juga dapat dilakukan dengan terapi lainnya. (Kusuma, 2016) melakukan penelitian mengenai terapi realitas untuk menurunkan tingkat depresi penyintas psoriasis. Hasil dari terapi yang dilakukan menyebutkan bahwa terapi realitas terbukti efektif untuk menurunkan derajat depresi penyintas psoriasi, namun 
dalam penelitian ini juga disebutkan bahwa terapi yang dilakukan masih memiliki kekurangan karena tidak mampu untuk menjangkau aspek spiritualitas dari penyintas psoriasis. Terapi realitas memiliki karakteristik yang hampir sama dengan Cognitive Behavior Therapy (CBT), pada praktiknya baik terapi realitas maupu CBT menemui sejumlah keterbatasan. Terapi perilaku memiliki kelemahan di mana klien sering kali kurang mampu mempertahankan perilaku barunya dalam jangka waktu yang lama ketika hubungan terapiutik antara klien dan terapis sudah tidak ada. Ketidakadaan hubungan tersebut akan mempengaruhi klien dalam mempertahankan perilaku barunya. Kemudian, keterbatasan lainnya adalah adanya penekanan pada situasi saat ini (here and now) (Palmer, 2011). Adapun untuk melengkapi dan mendukung temuan sebelumnya maka perlu dikembangkan kembali intervensi psikologi dari perspektif yang berbeda, yaitu agama.

Temuan-temuan yang menunjukkan tentang pentingnya peran agama dalam hidup mendorong peneliti untuk menggunakan pendekatan agama Islam dalam memberikan intervensi. Berdasarkan hal tersebut, dapat dirumuskan tujuan dari penelitian ini adalah untuk mengetahui efektivitas terapi membaca Al-Fatihah reflektif-intuitif dalam menurunkan tingkat depresi pada penyintas autoimun. Terapi membaca Al-Fatihah reflektif-intuitif berperan dalam menghasilkan rasa tenang pada individu dengan cara individu memaknai setiap kandungan ayat Al-Fatihah. Berdasarkan hal tersebut, peneliti tertarik untuk meneliti pengaruh terapi Al-Fatihah reflektif-intuitif untuk menurunkan tingkat depresi pada penyintas autoimun. Merujuk pada pandangan di atas, dapat diajukan hipotesis dalam penelitian ini, yaitu terapi Al-Fatihah reflektif-intuitif berpengaruh terhadap penurunan tingkat depresi pada penyintas autoimun pada saat pascates maupun saat tindak lanjut (follow up).

\section{METODE}

Subjek dalam penelitian ini adalah penyintas autoimun berjenis kelamin perempuan, beragama Islam dan berusia 22-50 tahun. Jenis kelamin perempuan dipilih karena berdasarkan pusat data informasi (2017) penyakit autoimun sebagian besar menyerang perempuan. Hal ini agar memudahkan peneliti untuk menyetarakan antara kelompok kontrol dan eksperimen yang bertujuan untuk mengurangi ancaman terhadap validitas internal eksperimen, seperti kelompok eksperimen dan kontrol yang tidak setara dikarenakan penempatan subjek penelitian (Hastjarjo, 2019). Subjek yang terlibat dalam penelitian ini merupakan subjek yang memiliki skor depresi pada kategori sedang atau tinggi.

Penelitian ini menggunakan kuasi eksperimen dengan pretest-posttest control group design. Pengambilan data prates (O1) dilakukan pada kelompok eksperimen maupun kelompok control. Pengambilan data pascates (O2) dilakukan segera setelah intervensi dilaksanakan, baik pada kelompok eksperimen maupun kelompok kontrol. Sementara pengambilan data tindak lanjut (O3) dilakukan sekurang-kurangnya dua 
pekan setelah pascates, baik pada kelompok eksperimen maupun kelompok kontrol. Selanjutnya, intevensi diberikan kepada kelompok eksperimen saja (Cook, 2015).

Tabel 1. Rancangan Penelitian

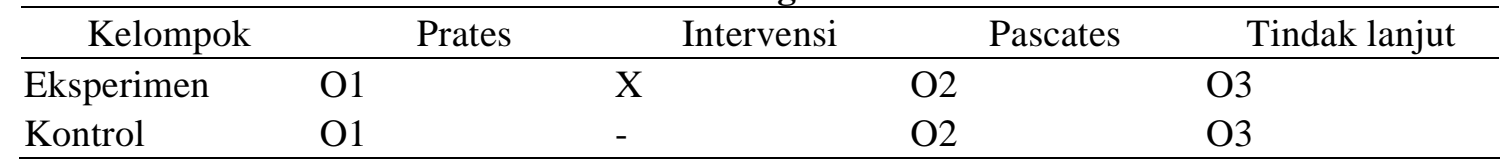

Keterangan :

$X$ : Terapi Al-Fatihah Reflektif-intuitif

O1: Pengukuran pertama (prates)

O2: Pengukuran kedua (pascates)

O3: Pengukuran ketiga (tindak lanjut)

Metode pengupulan data dalam penelitian ini adalah dengan menggunakan skala. Skala digunakan untuk memperoleh data kuantitatif terkait dengan tingkat depresi subjek. Penelitian ini menggunakan alat ukur Depression Anxiety Stress Scale (DASS) subtes depresi yang dikembangkan oleh (Lovibond \& Lovibond, 1995). Beberapa penelitian sudah menggunakan DASS dengan skala yang sudah diterjemahkan ke dalam bahasa Indonesia hasilnya valid dan reliabel sebagi alat ukur (Rahmawati dkk., 2008). Beberapa item yang terdapat dalam subtes depresi yaitu "saya merasa tidak ada hal yang dapat diharapkan di masa depan", "saya merasa kehilangan minat akan segala hal", "saya sepertinya tidak kuat lagi untuk melakukan suatu kegiatan" dan lain-lain. Skala DASS yang digunakan adalah skala yang sudah diterjemahkan ke dalam bahasa Indonesia dengan nilai reabilitas $\alpha=0.9483$ (Damanik, 2014). Skala ini menggunakan skala likert. Item dalam skala ini berupa pernyataan dengan empat pilihan, yaitu tidak pernah, kadang, sering, sangat sering. Skor yang diberikan mulai dari angka 1 sampai dengan 4. Bobot penilaian untuk pilihan tidak pernah: 0, kadang: 1, sering: 2, sangat sering: 3 .

Selain skala, penelitian ini juga menggunakan metode observasi. Observasi dilakukan untuk mendapatkan gambaran perilaku peserta pelatihan dan situasi atau kondisi selama pelatihan Al-Fatihah reflektif-intuitif berlangsung. Observasi dilakukan selama pelatihan berlangsung oleh observer. Adapun hal-hal yang akan diamati dalam pelaksanaan pelatihan terapi Al-Fatihah reflektif-intuitif, yaitu (a) Sikap, perilaku, dan aktivitas lain yang dilakukan peserta selama pelatihan berlangsung. (b) Cara fasilitator dalam memberikan materi, penguasaan materi, dan komunikasi yang dilakukan terhadap peserta pelatihan. (c) Fasilitas terkait pelaksanaan pelatihan yang dapat mendukung atau menghambat jalannya pelatihan koping religius. (d) Proses pelatihan mengenai metode, kesesuaian materi dengan rancangan, dan waktu yang digunakan dalam setiap sesinya. (e) Kondisi fisik peserta pelatihan, seperti pakaian yang dikenakan, kesehatan, dan sebagainya.

Penelitian terapi Al-Fatihah refelektif intuitif ini berbasis online dan berdasarkan literatur yang ada, sebelumnya belum pernah dilakukan dilakukan secara online. Ada beberapa tahapan prosedur penelitian. Pertama: Persiapan Penelitian. Penelitian diawali 
dengan melakukan analisis kebutuhan subjek penelitian melalui studi literatur ilmiah untuk mendapatkan gambaran kondisi penyintas autoimun. Setelah mendapatkan gambaran psikologis kondisi subjek penelitian, peneliti kemudian menentukan intervensi yang dapat diberikan untuk mengurangi permasalahan yang dialami penyintas autoimun, yaitu dengan memberikan terapi Al-Fatihah reflektif-intuitif. Peneliti bersama tim kemudian mengembangkan modul terapi Al-Fatihah reflektifintuitif dengan merujuk pada Maulana, Subandi dan Astuti (2016).

Kedua: Alat dan Materi Terapi. Persiapan yang dilakukan peneliti sebelum melakukan Terapi Al-Fatihah reflektif-intuitif, yaitu menyediakan Depression Anxiety Stress Scale (DASS) yang disusun oleh (Lovibond \& Lovibond, 1995), lembar informed consent, modul terapi Al-Fatihah reflektif-intuitif, materi terapi, lembar tugas, dan Aplikasi Zoom Meeting. Ketiga: Pengukuran Awal. Peserta terapi akan diberikan DASS sebelum terapi dimulai untuk mendapatkan data tingkat depresi pada pengukuran awal. Skala yang digunakan adalah skala yang telah diujicobakan serta dianalisis validitas dan reliabilitasnya.

Keempat: Pelaksanaan Terapi. Terapi Al-Fatihah reflektif-intuitif dilaksanakan dalam tiga kali pertemuan. Pertemuan pertama dibagi menjadi 2 sesi masing-masing sesi 50 menit, pertemuan kedua, dan ketiga dengan masing-masing 2 sesi dengan durasi 120 menit. Terapi akan dilaksanakan sesuai dengan modul yang telah dimodifikasi dari peneliti sebelumnya. Terapi Al-Fatihah reflektif-intuitif akan dilakukan oleh fasilitator yang merupakan seorang yang berprofesi sebagai psikolog serta dibantu oleh cofasilitator dan observer. Modul pelatihan yang digunakan merujuk pada modul pelatihan terapi refleksi Al-Fatihah yang digunakan oleh Maulana, Subandi dan Astuti (2016) yang kemudian dimodifikasi oleh peneliti.

Kelima: Pengukuran Akhir. Peserta terapi akan diminta untuk mengisi DASS subtes depresi, dan lembar evaluasi setelah terapi selesai dilaksanakan. Keenam: Pengukuran Tindak Lanjut. Tindak lanjut akan dilakukan minimal dua minggu setelah terapi Al-Fatihah reflektif-intuitif selesai dilakukan. Pada tahap ini peserta terapi diminta untuk mengisi DASS untuk mengetahui perubahan kondisi pada peserta.

Metode analisis data yang digunakan dalam penelitian ini adalah uji non parametrik dengan analisis Mann Whitney U-Test. Ujian analisis ini dimaksudkan untuk melihat perbedaan tingkat depresi subjek antara sebelum dan setelah diberikan intervensi berupa pelatihan terapi Al-Fatihah reflektif-intuitif dibandingkan dengan kelompok kontrol. Analisis data dilakukan menggunakan program Statistical Program for Socal Science (SPSS) 22.0 for Windows. 


\section{HASIL}

Subjek dalam penelitian ini adalah penyintas autoimun berjumlah sepuluh orang yang dikelompokkan dalam dua kelompok. Jumlah subjek pada kelompok eksperimen dan kelompok kontrol masing-masing berjumlah lima orang. Berikut rincian deskripsi subjek dalam penelitian dari hasil screening.

Tabel 2. Deskripsi Subjek Kelompok Eksperimen

\begin{tabular}{cccccc}
\hline Nama & Usia & Jenis Kelamin & $\begin{array}{c}\text { Lama menjadi } \\
\text { penyintas } \\
\text { Autoimun }\end{array}$ & Jenis Autoimun & Skor Depresi \\
\hline R & 37 & Perempuan & 3 Tahun & RA & $21($ Parah) \\
HY & 23 & Perempuan & 8 Tahnun & SLE & 31 (Parah) \\
I & 32 & Perempuan & 4 Tahun & SLE & 27 (Parah) \\
U & 30 & Perempuan & 4 Tahun & SLE & 16 (Sedang) \\
N & 35 & Perempuan & 10,5 Tahun & SLE & 22 (Parah) \\
\hline
\end{tabular}

Tabel 3. Deskripsi Subjek Kelompok Kontrol

\begin{tabular}{cccccc}
\hline Nama & Usia & Jenis Kelamin & $\begin{array}{c}\text { Lama menjadi } \\
\text { penyintas } \\
\text { Autoimun }\end{array}$ & $\begin{array}{c}\text { Jenis } \\
\text { Autoimun }\end{array}$ & Skor Depresi \\
\hline T & 33 & Perempuan & 4 Tahun & Scleroderma & 16 (Sedang) \\
E & 24 & Perempuan & 5 Tahun & SLE & 26 (Parah) \\
EA & 32 & Perempuan & 9 Tahun & SLE & 15 (Sedang) \\
VMA & 30 & Perempuan & 2 Tahun & RA & 31 (Sangat \\
D & 47 & Perempuan & 10 Tahun & SLE & Parah) \\
& & & & & \\
\hline
\end{tabular}

Pengukuran dilakukan menggunakan DASS Subtes Depresi pada kedua kelompok sebanyak tiga kali, yaitu sebelum pelatihan, setelah pelatihan, dan dua minggu setelah pelatihan (tindak lanjut), namun pada kelompok kontrol tidak diselingi pelatihan. Berikut deskripsi data penelitian pada kelompok eksperimen dan kelompok kontrol.

Tabel 4. Deskripsi Data Skor Depresi Kelompok Eksperimen

\begin{tabular}{|c|c|c|c|c|c|c|}
\hline Nama & $\begin{array}{l}\text { Prates } \\
\text { (I) }\end{array}$ & $\begin{array}{l}\text { Pascates } \\
\text { (II) }\end{array}$ & $\begin{array}{c}\text { Tindak } \\
\text { lanjut (III) }\end{array}$ & $\begin{array}{l}\text { Gained } \\
\text { Score } \\
\text { (I ke II) }\end{array}$ & $\begin{array}{l}\text { Gained } \\
\text { Score } \\
\text { (II ke III) }\end{array}$ & $\begin{array}{c}\text { Gained } \\
\text { Score } \\
\text { (I ke III) }\end{array}$ \\
\hline $\mathrm{R}$ & 21 (Parah) & $\begin{array}{c}14 \\
\text { (Sedang) }\end{array}$ & 14 (Sedang) & 7 & 0 & 7 \\
\hline HY & 31 (Parah) & $\begin{array}{c}24 \\
\text { (Parah) }\end{array}$ & 15 (Sedang) & 7 & 9 & 16 \\
\hline I & 27 (Parah) & $\begin{array}{c}31 \\
\text { (Sangat } \\
\text { Parah) }\end{array}$ & 13 (Ringan) & -4 & 18 & 14 \\
\hline $\mathrm{U}$ & 16 (Sedang) & $\begin{array}{c}14 \\
\text { (Sedang) }\end{array}$ & 9 (Normal) & 2 & 5 & 7 \\
\hline $\mathrm{N}$ & 22 (Parah) & $\begin{array}{c}14 \\
\text { (Sedang) }\end{array}$ & 11 (Ringan) & 8 & 3 & 11 \\
\hline
\end{tabular}


Berdasarkan tabel 4 di atas dapat dilihat bahwa terjadi perubahan skor depresi sebelum dan sesudah pelatihan. Subjek HY dan U mengalami penurunan pada skor depresi namun masih berada pada kategori yang sama, $\mathrm{R}$ dan $\mathrm{N}$ mengalami penurunan skor depresi dan penurunan kategori dan I mengalami peningkatan skor depresi. Pada pengukuran tindak lanjut setelah dua minggu pada pengukuran pascates, kelima subjek juga mengalami penurunan skor depresi.

Tabel 5. Deskripsi Data Skor Depresi Kelompok Kontrol

\begin{tabular}{|c|c|c|c|c|c|c|}
\hline Nama & $\begin{array}{l}\text { Prates } \\
\text { (I) }\end{array}$ & $\begin{array}{l}\text { Pascates } \\
\text { (II) }\end{array}$ & $\begin{array}{l}\text { Tindak lanjut } \\
\text { (III) }\end{array}$ & $\begin{array}{l}\text { Gained } \\
\text { Score } \\
\text { (I ke II) }\end{array}$ & $\begin{array}{l}\text { Gained } \\
\text { Score } \\
\text { (II ke III) }\end{array}$ & $\begin{array}{l}\text { Gained } \\
\text { Score } \\
\text { (I ke III) }\end{array}$ \\
\hline $\mathrm{T}$ & 16 (Sedang) & $\begin{array}{c}21 \\
\text { (Parah) }\end{array}$ & 26 (Parah) & -5 & -5 & -10 \\
\hline E & 26 (Parah) & 16 (Sedang) & 25 (Parah) & 10 & -9 & 1 \\
\hline EA & 15 (Sedang) & $\begin{array}{c}34 \\
\text { (Sangat } \\
\text { Parah) }\end{array}$ & $\begin{array}{l}38 \text { (Sangat } \\
\text { Parah) }\end{array}$ & -19 & -4 & -23 \\
\hline VMA & $\begin{array}{l}31 \text { (Sangat } \\
\text { Parah) }\end{array}$ & $\begin{array}{c}27 \\
\text { (Parah) }\end{array}$ & $\begin{array}{l}32 \text { (Sangat } \\
\text { Parah) }\end{array}$ & 4 & -5 & -1 \\
\hline D & 15 (Sedang) & 15 (Sedang) & 24 (Parah) & 0 & -9 & -9 \\
\hline
\end{tabular}

Berdasarkan tabel 5 di atas dapat dilihat bahwa subjek T dan EA pada kelompok kontrol mengalami peningkatan skor depresi pada pengukuran pascates. Subjek D tidak mengalami perubahan sedangkan E dan VMA mengelami penurunan skor depresi pada pengukuran pascates. Pada pengukuran tindak lanjut setelah dua minggu pada pengukuran pascates, kelima subjek pada kelompok kontrol mengalami kenaikan skor depresi.

Tabel 6. Deskripsi Data Statistik

\begin{tabular}{cccccccccc}
\hline & \multicolumn{4}{c}{ Kelompok Eksperimen } & \multicolumn{4}{c}{ Kelompok Kontrol } \\
\cline { 3 - 10 } & & Min & Max & Mean & SD & Min & Max & Mean & SD \\
\hline \multirow{3}{*}{ Depresi } & Prates & 16 & 31 & 23.40 & 5.771 & 15 & 31 & 20.60 & 7.436 \\
& Pascates & 14 & 31 & 19.40 & 7.797 & 15 & 34 & 22.60 & 7.956 \\
& Tindaklanjut & 9 & 15 & 12.40 & 2.498 & 24 & 38 & 29.00 & 5.916 \\
\hline
\end{tabular}

Berdasarkan tabel 6 deskripsi data statistik, dapat dilihat bahwa skor depresi kelompok eksperimen mengalami penurunan setelah mengikuti pelatihan Al-Fatihah reflektif-intuitif dari pengukuran prates $($ Mean $=23.40 ; \mathrm{SD}=5.771)$ dan pada pengukuran pascates $($ Mean $=84.25$; SD $=7.797$ ). Kemudian, pada pengukuran tindak lanjut, kelompok eksperimen juga mengalami penurunan skor depresi $($ Mean $=12.40$; SD = 2.498). Pada kelompok kontrol terjadi peningkatan skor depresi dari pengukuran prates $($ Mean $=20.60 ; \mathrm{SD}=7.436)$ dan pada pengukuran pascates $($ Mean $=22.60 ; \mathrm{SD}=7.956)$. Kemudian, pada pengukuran tindak lanjut, kelompok kontrol juga mengalami peningkatan skor depresi (Mean $=29.00 ; \mathrm{SD}=5.916$ ). 
Terapi Al-Fatihah reflektif-intuitif ini dilakukan secara online, untuk mengetahui apakah terapi ini dapat diterima dengan baik oleh subjek maka dilakukan manipulation check. Hal ini dilakukan untuk mengetahui dampak terapi terhadap pengetahuan subjek dalam menerapkan terapi Al-Fatihah reflektif-intuitif. Penyajian tes ini dilakukan dengan memberikan sejumlah pernyataan mengenai terapi Al-Fatihah reflektif-intuitif. Masingmasing pertanyaan diberikan pilihan jawaban benar atau salah, sehingga subjek memilih salah satu berdasarkan pemahamannya (Azwar, 2016). Total item dalam skala ini adalah 13 buah dengan penilaian pernyataan yang dijawab benar akan mendapatkan nilai 1, sedangkan jawaban salah akan mendapatkan nilai 0 . Total skor jika seluruh jawaban tepat adalah 13. Tabel berikut menunjukkan hasil tes pengetahuan subjek.

Tabel 7. Deskripsi Data Manipulation Check

\begin{tabular}{cccc}
\hline Nama & Prates & Pascates & Gained score \\
\hline R & 10 & 12 & 2 \\
HY & 10 & 11 & 1 \\
I & 8 & 11 & 3 \\
U & 9 & 10 & 1 \\
N & 10 & 11 & 1 \\
\hline
\end{tabular}

Berdasarkan hasil prates dan pascates pengetahuan terapi Al-Fatihah reflektifintuitif, tabel di atas menunjukkan bahwa 5 partisipan mengalami peningkatan pengetahuan.

Tabel 8. Uji Beda Skor Manipulation Check

\begin{tabular}{cc} 
& Posttest-Pretest \\
\hline $\mathrm{Z}$ & -2.060 \\
\hline Asymp.Sig.(2-tailed) & .039
\end{tabular}

Berdasarkan uji Wilcoxon diperoleh nilai $\mathrm{Z}$ partisipan -2.060 dengan nilai signifikansi $0.039(\mathrm{p}<0.05)$. Adanya perbedaan signifikan semakin menguatkan bahwa terapi Al-Fatihah reflektif-intuitif dapat meningkatkan pengetahuan mengenai surat AlFatihah untuk menurunkan tingkat depresi subjek. Selain itu hal ini juga menunjukkan bahwa terapi Al-Fatihah reflektif-intuitif dapat dilakukan secara online.

Uji hipotesis riset ini menggunakan metode nonparametrik karena jumlah subjek dalam penelitian yang terbatas. Adapun hipotesis riset ini adalah terapi Al-Fatihah reflektif-intuitif berpengaruh dalam usaha menurunkan depresi pada penyintas autoimun. Uji hipotesis dilakukan dengan metode analisis Mann Whitney U-Test.

Tabel 9. Hasil Uji Hipotesis

\begin{tabular}{llll}
\hline & Pengukuran & $\mathrm{Z}$ & $\mathrm{P}$ \\
\hline \multirow{3}{*}{ Depresi } & Prates & 0.949 & 0.343 \\
& Pascates & 1.163 & 0.245 \\
& Tindak lanjut & 2.611 & 0.009 \\
\hline
\end{tabular}


Tabel 9 menunjukkan hasil analisis Mann Whitney pada pengukuran prates, pascates, dan tindak lanjut. Pada pengukuran prates, hasil analisis menunjukkan nilai $\mathrm{Z}$ 0.949 dan koefisien signifikansi 0,343 (p>0,05). Hal ini berarti tidak ada perbedaan yang signifikan tingkat depresi antara kelompok eksperimen dan kelompok kontrol saat pengukuran prates. Selanjutnya, dari pengukuran pascates diketahui nilai Z 1.163 dan koefisien signifikansi 0,245 ( $p>0,05$ ). Dari pengukuran pascates ini dapat diketahui antara kelompok kontrol dan kelompok eksperimen tidak memiliki perbedaan tingkat depresi. Terakhir, saat pengukuran tindak lanjut diperoleh nilai Z 2,611 dan koefisien signifikansi $0,009$ ( $\mathrm{p}<0,05)$. Dari sini diketahui bahwa antara kelompok eksperimen dan kelompok kontrol ada perbedaan tingkat depresi saat pengukuran tindak lanjut.

Tabel 10. Uji Beda Skor Depresi pada Kelompok Eksperimen dan Kontrol

\begin{tabular}{lllllll}
\hline \multirow{2}{*}{ Depresi } & Pengukuran & \multicolumn{2}{c}{ Kelompok Eksperimen } & \multicolumn{2}{c}{ Kelompok Kontrol } \\
\cline { 2 - 7 } & $\begin{array}{l}\text { Prates- } \\
\text { Pascates }\end{array}$ & 1.490 & 0.136 & 0.67 & 0.365 & 0.715 \\
\cline { 2 - 7 } & $\begin{array}{l}\text { Pascates- } \\
\text { Tindak lanjut }\end{array}$ & 1.826 & 0.068 & 0.82 & 2.041 & 0.041 \\
\hline $\begin{array}{l}\text { Prates-Tindak } \\
\text { lanjut }\end{array}$ & 2.032 & 0.042 & 0.91 & 1.625 & 0.104 \\
\hline
\end{tabular}

Tabel 10 menunjukkan hasil analisis data tingkat depresi pada kelompok eksperimen dan kelompok kontrol, baik pebedaan hasil pengkuran antara prates-pascates, pascates-tindak lanjut, maupun prates-tindak lanjut. Uji beda tingkat depresi menggunakan statistik non-parametrik dengan analisis Wilcoxon. Pada pengukuran kelompok eksperimen antara prates - pascates diketahui nilai Z 1.490 dan koefisien signifikansi 0.136 ( $>00.05)$. Ini berarti tidak ada perbedaan tingkat depresi pada kelompok eksperimen antara prates - pascates. Selanjutnya, pada saat pengukuran pascates - tindak lanjut diperoleh nilai Z 1.826 dan koefisien signifikansi 0.068 ( $p>0.05$ ). Hal ini berarti bahwa pada kelompok eksperimen tidak ada perbedaan yang signifikan antara tingkat depresi pada saat pascates dan tindak lanjut. Berikutnya adalah hasil uji beda antara prates dan tindaklanjut menunjukkan nilai Z 2.032 dan koefisien signifikansi 0.042 ( $\mathrm{p}<0.05$ ). Hal tersebut menunjukkan bahwa pada kelompok eksperimen terdapat perbedaan tingkat depresi yang signifikan antara prates dan tindaklanjut. Hasil lain dari analisis ini menunjukkan bahwa pada prates-pascates memiliki nilai effect size sebesar 0.67 , pascates-tindaklanjut memiliki nilai effect size sebesar 0,82 dan pada pratestindaklanjut memiliki nilai effect size sebesar 0.91. Hal ini berarti pelatihan membaca AlFatihah reflektif-intuitif memiliki dampak yang besar terhadap tingkat depresi setelah melalui pemaknaan oleh peserta.

Masih terkait Tabel 10, diketahui juga bahwa tidak ada perbedaan depresi pada kelompok kontrol antara pengukuran prates-pascates, pengukuran pascates-tindak lanjut, dan pengukuran prates-tindak lanjut. Saat dilakukan pengukuran antara prates dan 
pascates didapatkan nilai Z 0.365 dan koefisien signifikansi 0.715 ( $\mathrm{p}>0,05)$. Hal tersebut berarti tidak terdapat perbedaan yang meyakinkan antara depresi saat pengukuran prates dan pengukuran pascates. Berikutnya, uji beda depresi antara pascates dan tindak lanjut menunjukkan nilai Z 2.041 dan koefisien signifikansi 0.041 ( $p<0.05)$. Hal ini berarti ada penurunan depresi dari pascates ke tindak lanjut. Sekalipun demikian, secara keseluruhan, yaitu dilihat dari pengukuran prates ke pengukuran pasca tes diperoleh Z 1.625 dan koefisien siginifikansi 0.104 ( $>>0,05)$. Itu berarti tidak ada penurunan depresi dari prates ke tindak lanjut.

\section{PEMBAHASAN}

Tujuan dari penelitian ini adalah mengetahui efektivitas terapi Al-Fatihah reflektifintuitif dalam menurunkan depresi pada penyintas autoimun. Berdasarkan pengolahan data secara statistik diketahui bahwa hipotesis penelitian ada penurunan depresi saat setelah mengikuti Terapi Al-Fatihah refelektif-intuitif saat pascates ditolak. Hasil uji hipotesis menggunakan mann whitney menunjukkan bahwa nilai signifikansi pada saat prates-pascates tidak ada perbedaan $\mathrm{p}=0.245$ ( $\mathrm{p}>0.05)$. Berdasarkan pengolahan data selanjutnya yang dilakukan secara statistic diketahui hipotesis yang berbunyi terapi Al-Fatihah reflektif-intuitif efektif dalam menurunkan depresi penyintas autoimun saat follow up diterima.

Hasil dua hipotesis di atas menunjukan bahwa terapi Al-Fatihah refelektif-intuitif tidak efektif dalam menurunkan depresi penyintas autoimun ketika pengukuran dilakukan secara langsung setelah terapi. Namun, hasil penelitian menunjukkan bahwa terapi al-Fatihah reflektif-intuitif efektif dalam menurunkan depresi saat pengukuran follow up, yaitu dua pekan setelah tritmen diberikan. Hasil ini diperkuat oleh uji hipotesis dengan menggunakann Wilcoxon. Hasil uji beda menggunakan wilcoxon pada prates-tindaklanjut didapatkan nilai $\mathrm{p}=$ 0.042 ( $\mathrm{p}<0.05)$. Hal tersebut menunjukkan bahwa terdapat perbedaan tingkat depresi yang signifikan antara kelompok eksperimen dan kelompok kontrol setelah dua minggu dilakukan intervensi.

Berdasarkan data tersebut dapat diketahui bahwa penurunan depresi pada subjek membutuhkan waktu sehingga efektifitas terapi Al-Fatihah reflektif intuitif baru dapat dirasakan dua minggu setelah dilakukannya terapi. Hasil dari penelitian ini sejalan dengan penelitian yang dilakukan oleh (Ningsih, 2020), yang menunjukkan bahwa perubahan skor DASS pada pasien kanker baru menunjukan penurunan pada saat tindaklanjut. Menurut (Irawati dkk., 2011), unsur religiusitas yang dilakukan secara terus menerus dan berkelanjutan akan memperkuat terapi. Anggraieni dan Subandi (2014) juga menyebutkan bahwa peningkatan religiusitas didapatkan dengan cara mengamalkan ajaran agama secara terus menerus sehingga mampu menurukan depresi. Sejalan dengan penelitian yang dilakukan oleh Hayatussofiyyah, Nashori dan Rumiani (2017) bahwa dalam suatu proses terapi diperlukan suatu penguat yang harus dilakukan oleh individu dalam rentang waktu yang lama seperti sebuah keyakinan agama yang akan memuncukan tingkat religiusitas seorang individu. Dengan demikian, Terapi Al-Fatihah Reflektif-intuitif mampu memberikan dampak jangka 
panjang yang baik walaupun harus melewati proses perubahan yang memakan waktu.

Berdasarkan hasil wawancara yang dilakukan pada saat tindak lanjut, subjek mengatakan bahwa ketika membaca surat Al-Fatihah secara reflektif-intuitif dalam waktu yang cukup lama mereka merasakan ketenangan hati. (Ridlwan, 2014) mengungkapkan bahwa membaca Al-Quran dapat menjadi obat bagi hati yang gelisah akan hal duniawi, hal ini karena membaca Al Qur'an dapat menghubungkan hari pembacanya dengan Allah apabila dilakukan secara konsisten dan dilakukan dengan penghayatan.

Hasil penelitian yang menunjukkan terapi membaca al-Fatihah Reflektif-Intuitif efektif dalam menurunkan depresi didukung oleh hasil data kualitatif. Hasil riset kualitatif menunjukkan bahwa terapi Al-Fatihah reflektif-intuitif memberikan manfaat bagi subjek. Subjek merasa bersyukur masih diberikan nikmat dari Allah SWT meskipun dalam keadaan sakit. Hal lain yang ditemukan selama proses terapi berlangsung adalah seluruh subjek dalam kelompok eksperimen yang mengikuti pelatihan Al-Fatihah reflektif-intuitif muncul perasaan senang, lebih bersemangat, bersyukur dan muncul perasaan tenang di dalam hati. Subjek menyadari masih banyak hal dalam hidup subjek yang masih bisa dilakukan. Selain itu masing-masing subjek mengaku menjadi lebih bisa memaknai arti dari setiap ayat dari surat Al-Fatihah. Subjek juga merasakan getaran ketika membaca Al-Fatihah secara reflektifintuitif serta mengakui menjadi merasa lebih dekat dengan Allah. Hal tersebut juga diungkapkan oleh (Reza, 2015) melalui penelitiannya menungkapkan bahwa bahwa seseorang cenderung akan memiliki kesehatan mental yang stabil apabila memahami dan menghayati pelaksanaan ibadah yang dilakukan.

Secara garis besar pelatihan membaca Al-Fatihah reflektif-intuitif pada penyintas autoimun berjalan lancar dan sesuai dengan rancangan intervensi. Fasilitator dapat menjalankan tugasnya dengan baik selama pelatihan berlangsung. Latar belakang fasilitator sebagai seorang psikolog yang sudah beberapa kali memberikan pelatihan Al-Fatihah reflektif-intuitif dipandang mendukung proses penyampaian dan building rapport antara fasilitator dan semua subjek. Kemudian, semua subjek juga tampak antusias mendengarkan dan aktif dalam proses pelatihan yang dipandu oleh fasilitator.

Adapun sejumlah kekurangan dalam penelitian ini yang kemudian menjadi keterbatasan dalam penelitian. Pelatihan ini dilakukan secara online sehingga sangat tergantung pada kualitas koneksi jaringan internet. Salah satu subjek dalam penelitian mengalami kendala tersebut sehingga saat subjek menyampaikan apa yang sedang dirasakan terputus-putus. Selain itu, kendala jaringan juga mengakibatkan subjek tidak dapat menyalakan video sehingga proses observasi tidak berjalan secara optimal.

\section{KESIMPULAN}

Berdasarkan analisis data statistik yang telah dilakukan dapat disimpulkan bahwa Terapi Al-Fatihah reflektif-intuitif efektif untuk menurunkan depresi pada penyintas autoimun. Hasil penelitian menunjukan bahwa terapi Al-Fatihah refelektif intuitif tidak secara langsung efektif dalam menurunkan depresi penyintas autoimun. Hasil uji beda 
menunjukkan bahwa terdapat perbedaan tingkat depresi yang signifikan antara kelompok eksperimen dengan kelompok kontrol setelah dua minggu dilakukan intervensi. Berdasarkan data tersebut dapat diketahui bahwa penurunan depresi pada subjek membutuhkan waktu sekitar dua minggu sehingga efektifitas terapi Al-Fatihah reflektif intuitif baru dapat dirasakan. Berdasarkan hasil data kualitatif, Subjek merasakan bahwa Terapi Al-Fatihah Reflektif-intuitif dapat menenangkan persaan dan dapat dijadikan alternatif coping dalam permasalahan yang sedang dialami subjek. Selian itu, Subjek jlebih mampu menerima keadaan saat ini dengan rasa syukur.

\section{SARAN DAN REKOMENDASI}

Selanjutnya, disampaikan sejumlah saran. Pertama: Saran bagi penelitian selanjutnya. Berdasarkan hasil dari pelaksanaan dan evaluasi penelitian, maka hal yang dapat disarankan untuk dijadikan perbaikan bagi penelitian selanjutnya yaitu pertimbangan untuk memperpanjang pertemuan terapi. Hal ini berkaitan dengan penurunan skor depresi membutuhkan waktu yang cukup panjang. Peneliti selanjutnya dapat mempertimbangkan rentang waktu pertemuan. Hal ini berkaitan dengan tugas rumah atau monitoring yang dilakukan subjek sehingga tugas rumah dapat dilakukan dengan lebih baik untuk melihat perubahan dan konsistensi yang dilakukan oleh subjek. Proses monitoring juga perlu dilakukan pada periode pasca tes hingga tindaklanjut. Hal ini untuk memastikan bahwa perubahan yang terjadi pada subjek merupakan efek dari terapi bukan karena varaiabel lainnya.

Kedua: Saran bagi subjek penelitian. Subjek penelitian ke depannya diharapkan mampu menerapkan materi-materi pelatihan Al-Fatihah reflektif-intuitif secara konsisten dalam kehidupan sehari-hari. Subjek juga dapat membagikan informasi manfaat membaca Al-fatihah secara reflektif dan intuitif kepada penyintas autoimun lainnya. 


\section{DAFTAR PUSTAKA}

Ansyah, E. H., \& Hadi, C. (2017). Psikologi Al-Fatihah: Solusi untuk Mencapai Kebahagiaan yang Sebenarnya. Jurnal Psikologi Islam, 4(December), 107-120.

Asyafah, A. (2016). Metode Tadabur Qurani Dalam Pembelajaran PAI (Edisi Revi). CV Maulana Media Grafika.

Cook, T. D. (2015). Quasi-expermintal design. Wiley Encyclopedia of Management.

Diantini, D. M. A., Ulandari, N. L., Wirandani, N. K. N. S., Niruri, R., \& Kumara, K. D. (2016). Et Al., 2008). 1. Jurnal Farmasi Udayana, 5(2), 30-34.

Elliya, R., Maulana, I., \& Hidayati, M. (2018). Pengaruh Terapi Religiusitas Terhadap Gejala Depresi Pada Lansia Beragama Islam Di Uptd Pelayanan Sosial Tresna Werdha Natar Lampung Selatan Tahun 2017. Holistik Jurnal Kesehatan, 12(2), $118-125$.

Fairweather, D., Frisancho-Kiss, S., \& Rose, N. R. (2008). Sex differences in autoimmune disease from a pathological perspective. American Journal of Pathology, 173(3), 600-609. https://doi.org/10.2353/ajpath.2008.071008

Irawati, D., Subandi, \& Kumolohadi, R. (2011). Terapi Kognitif Perilaku REligius untuk Menurunkan Kecemasan terhadap Kematian pada Penderita HIV/AIDS. Jurnal Intervensi Psikologi, 3(2), 169-186. https://doi.org/10.20885/intervensipsikologi.vol3.iss2.art2

Julianto, V., \& Etsem, M. B. (2011). The Effect of Reciting Holy Qur'an toward Shortterm Memory Ability Analysed trought the Changing Brain Wave. The Effect of Reciting Holy Qur'an toward Short-term Memory Ability Analysed trought the Changing Brain Wave, 38(1), 17-29. https://doi.org/10.22146/jpsi.7661

Julianto, V., Indriyani, R., Munir, M. M., Sulantri, C., \& Hasanah, S. M. (2017). Pengaruh Membaca Al Fatihah Reflektif Intuitif terhadap Penurunan Tingkat Kecemasan Berbicara di Depan Umum pada Mahasiswa Prodi Psikologi UIN Sunan Kalijaga Yogyakarta. Jurnal Psikologi, 13(2), 162. https://doi.org/10.24014/jp.v13i2.4299

Julianto, V., \& Subandi, -. (2015). Membaca Al Fatihah Reflektif Intuitif untuk Menurunkan Depresi dan Meningkatkan Imunitas. Jurnal Psikologi, 42(1), 34. https://doi.org/10.22146/jpsi.6941

Kane, R. (2006). Hope Beyond the Hurt: Spirituality and the Dual Diagnosis of Acquired Brain Injury and Psychiatric Disorder. 2(April), 1-19.

Khan, N., Ahmad, N. B., Beg, A. H., Fakheraldin, M. A. I., Alla, A. N. A., \& Nubli, M. (2010). Mental and spiritual relaxation by recitation of the holy Quran. 2nd International Conference on Computer Research and Development, ICCRD 2010, 863-867. https://doi.org/10.1109/ICCRD.2010.62

Kiecolt-Glasera, J. K., \& Glaser, R. (2002). Depression and immune function Central pathways to morbidity and mortality Janice. Journal of Psychosomatic Research, 53, 873-876. https://doi.org/10.1177/1526602815593537 
Kusuma, W. (2016). Terapi Realitas Untuk Menurunkan Derajat Depresi Pasien Psoriasis. Masters Thesis, Universitas Sebelas Maret, 12-136.

Laeli, S. A. (2016). Pengalaman Sakit Pada Penderita Lupus: Interpretative Phenomenological Analysis khas. Pada umumnya penderita lupus ingin terus berkembang walaupun terdapat keterbatasan. 5(3), 566-571.

Lovibond, P., \& Lovibond, S. (1995). Pergamon The Structure Of Negative Emotional States: Scales ( Dass ) With The Beck Depression And. Behaviour research and therapy, 33(3), 335-343.

Mahmuda, I. R., Jumaini, \& Agrina. (2018). Perbedaan Efektivitas Antara Membaca Dengan Mendengarkan Surah Al Fatihah Terhadap Skor Halusinasi. JOM FKp, 2, 318-327.

Maria, D., \& Ediati, A. (2018). Hubungan Antara Ketabahan Dengan Kesejahteraan Psikologis Pada Wanita Penyandang Lupus Eritematosus Sistemik. Empati, 7(2), 120-131.

Matcham, F., Rayner, L., Steer, S., \& Hotopf, M. (2013). The prevalence of depression in rheumatoid arthritis: A systematic review and meta-analysis. Rheumatology (United Kingdom), 52(12), 2136-2148. https://doi.org/10.1093/rheumatology/ket169

Matlin, M. W. (2009). Cognition (seventh). John Wiley \& Sons, Inc. All rights reserved.

Ningsih, S. (2020). Pengaruh terapi al-fatihah reflektif intuitif terhadap stres pada pasien kanker.

Ong, A. D., Bergeman, C. S., Bisconti, T. L., \& Wallace, K. A. (2006). Psychological resilience, positive emotions, and successful adaptation to stress in later life. Journal of Personality and Social Psychology, 91(4), 730-749. https://doi.org/10.1037/0022-3514.91.4.730

Parker, M., Roff, L. L., Klemmack, D. L., Koenig, H. G., Baker, P., \& Allman, R. M. (2003). Religiosity and mental health in southern, community-dwelling older adults. Aging and Mental Health, 7(5), 390-397. https://doi.org/10.1080/1360786031000150667

Penninx, B. W. J. H., Milaneschi, Y., Lamers, F., \& Vogelzangs, N. (2013). Understanding the somatic consequences of depression: Biological mechanisms and the role of depression symptom profile. BMC Medicine, 11(1), 1-14. https://doi.org/10.1186/1741-7015-11-129

Pryce, C. R., \& Fontana, A. (2016). Neurotrophins and. Depression in autoimmune diseases, 2016, 139-154. https://doi.org/10.1007/7854

Rahmawati, I., Haroen, H., \& Juniarti, N. (2008). Perbedaan Tingkat Stres Sebelum Dan Sesudah Terapi Musik Pada Kelompok Remaja Di Panti Asuhan Yayasan Bening Nurani Kabupaten Sumedang. Fakultas Ilmu Keperawatan Universitas Padjajaran, October, 1-19. 
Reza, I. F. (2015). Efektivitas Pelaksanaan Ibadah Dalam Upaya Mencapai Kesehatan Mental. Psikis : Jurnal Psikologi Islami, 1(1), 105-115.

Ridlwan, B. (2014). Kelebihan mempelajari Al Qur'an. Al Ta'dib, 4, 47-68.

Robbins. (2010). Buku Ajar Patologi, Edisi 7. Dalam Nasional (Vol. 2).

Sinaga, D. (2013). Pengaruh stress psikologis terhadap pasien psoriasis. Jurnal Ilmiah WIDYA, 1(1), 129-134.

Singh, S. P., Wal, A., Wal, P., Srivastava, V., Tiwari, R., \& Sharma, R. D. (2016). Understanding Autoimmune Disease: An Update Review. International Journal of Psychosocial Rehabilitation, 3(3), 51-65. https://doi.org/10.37200/IJPR/V23I6/PR190741

US Department of Health and Human Services. (2005). Progress in Autoimmune Diseases Research. National Institutes of Health, 05-5140(5), 1-129.

Vojdani, A. (2014). A potential link between environmental triggers and autoimmunity. Autoimmune Diseases, 2014. https://doi.org/10.1155/2014/437231

Wahyuningsih, A., \& Surjaningrum, E. R. (2013). Kesejahteraan Psikologis pada Orang dengan Lupus ( Odapus ) Wanita Usia Dewasa Awal Berstatus Menikah. JURNAL Psikologi Klinis dan Kesehatan Mental, 1(3), 154-161.

Yanda, O. N., Umari, T., \& Saam, Z. (t.t.). The Effect Of Al-Fatihah Reflection Therapy ( Art) To Improve Students 'Positive Thinking Through Group Guidance At Sma Negeri 5 Pekanbaru Melalui Bimbingan Kelompok Di Sma Negeri 5. 6, 1-11.

Yudhani, E., Suharti, V., Adya, A., \& Utami, E. S. (2017). Efektivitas Membaca Dan Mentadabburi Al-Qur'an Dalam Menurunkan Kecemasan Siswa Yang Akan Menghadapi Ujian Sekolah. Jurnal Psikoislamedia, 2(April), 23-31. 